\title{
Unidad de Posgrado en Estomatología: 30 años en un contexto diferente
}

\author{
Postgraduate Dentistry Unit \\ 30th anniversary in a different situation
}

La conmemoración de un aniversario y sobre todo de una década más en una institución permite hacer una reflexión desde sus orígenes, los hechos que marcaron hitos, los objetivos logrados, el aporte brindado a la sociedad y el planteamiento de nuevos retos y metas hacia el futuro.

Es así que este año, al conmemorar el trigésimo aniversario de la Unidad de Posgrado en Estomatología debemos rendir un homenaje a todos aquellos que con su visión, esfuerzo e innovación lograron construir y posicionar esta institución educativa como referente en la región, brindando profesionales debidamente capacitados al servicio de la educación y de la salud bucal.

Desde su conceptualización, el Dr. Roberto Beltrán Neira, fundador de nuestra Facultad, consideró como uno de sus ejes la formación de especialistas, es así que en los primeros años, el esfuerzo estuvo dirigido a la enseñanza a través de educación continua en las diversas especialidades. Es en 1990, durante el Decanato del Dr. Ramón Castillo Mercado que se da inicio a los programas escolarizados en la Dirección de Estudios de Posgrado, asumiendo esta responsabilidad el Dr. Wilson Delgado Azañero como primer Director, quién durante los primeros 18 años impulsó la creación de programas de especialidades principalmente clínicos y se afianzó el desarrollo de estos, así mismo se iniciaron los programas de Maestrías y Doctorado y el crecimiento en infraestructura con la ampliación del tercer y cuarto piso de la Clínica Estomatológica Central, así como la Sede de San Isidro; destinadas a brindar más oportunidades a un mayor número de profesionales, por ello el merecido reconocimiento como epónimo de la Unidad de Posgrado.

En la primera década de este siglo y durante la dirección del Dr. Freddie Williams Díaz, la unidad de posgrado se implementó con equipos de alta tecnología posicionándonos dentro de las instituciones educativas líderes en Latinoamérica, así también se inició la regularización de los planes de estudio de los distintos programas, continuando con la creación de programas en áreas de especialización relacionadas con la gestión, administración, auditoria y salud pública en estomatología.

Este último quinquenio el esfuerzo se centró en licenciar los planes curriculares de 15 programas de segunda especialidad profesional ante SUNEDU, así como la participación constante y activa desde el primer proceso de admisión, en 2015, a través del Consejo Directivo del Residentado Odontológico - CODIRO en siete especialidades, brindando al país especialistas altamente calificados con una formación integral, tecnológica, académica y humana en beneficio de la población. 
Paralelamente se sigue desarrollando y cumpliendo nuestro objetivo de formación y capacitación constante a profesionales, a través de los programas de diplomados y cursos de educación continua que brindan alternativas bajo diferentes modalidades, tiempos y estrategias en las diferentes áreas.

Por otro lado el avance en los programas de Maestrías y Doctorado han permitido brindar una mayor oferta académica así como la implementación de laboratorios no solo para el desarrollo de tesis, sino además para establecer nuevas líneas de investigación conducentes a la formulación y creación de nuevos productos.

Al cumplir los 30 años en medio de una coyuntura muy particular como es la pandemia provocada por el COVID 19, bajo un aislamiento social obligatorio por más de 100 días, con miles de compatriotas fallecidos y otros cientos de miles más infectados, un sistema de salud colapsado, la economía nacional duramente golpeada, altas tasas de desempleo y una gran incertidumbre para encarar el presente.

Frente a este escenario los retos que se presentan para cumplir los compromisos adquiridos se torna muy difíciles, pero genera la oportunidad de innovar, adaptarse y poder enfrentar esta nueva realidad, la que es posible gracias al entusiasmo y capacidad resolutiva de nuestros docentes quienes de manera inmediata hicieron la transición y migración hacia la virtualización en una primera etapa de todos los contenidos teóricos y posteriormente la incorporación de demostraciones a través de plataformas, así también la disposición, iniciativa y responsabilidad de nuestros estudiantes por aceptar y adaptarse de manera decisiva ante esta realidad, sumado al compromiso de nuestros residentes, de algunas áreas, para incorporarse a sus actividades presenciales en atención a la emergencia sanitaria.

En estas circunstancias, docentes, estudiantes, personal administrativo y autoridades, nos preparamos para el retorno a la "nueva normalidad", aprovechando las ventajas de la educación on line, optimizando las oportunidades de capacitación continua, estableciendo protocolos de bioseguridad y reglas de convivencia que garanticen nuestra salud así como la de los pacientes y sobre todo con el compromiso y esperanza de seguir siendo una institución líder.

Mg. Janett Mas López ${ }^{1 a, b, c}$

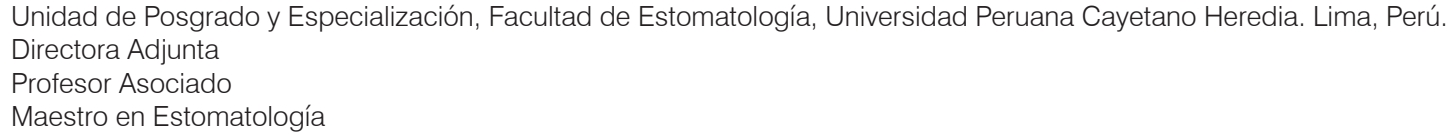

